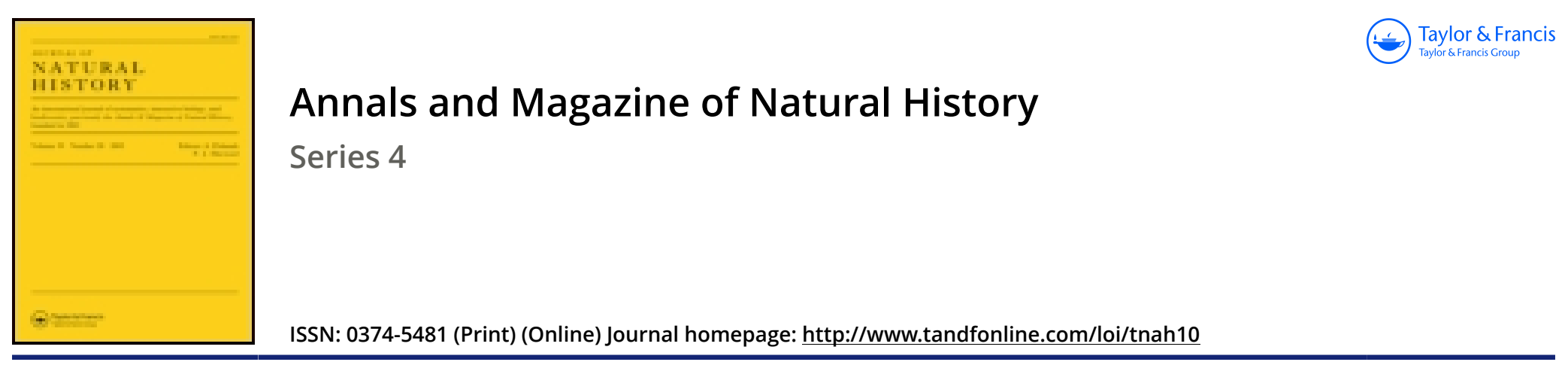

\title{
On some extinct types of horned Perissodactyles
}

\section{Edward D. Cope}

To cite this article: Edward D. Cope (1874) On some extinct types of horned Perissodactyles, Annals and Magazine of Natural History, 13:77, 405-406, DOI: $10.1080 / 00222937408680892$

To link to this article: http://dx.doi.org/10.1080/00222937408680892

$$
\text { 曲 Published online: } 13 \text { Oct } 2009 .
$$

Submit your article to this journal ๔

Џll Article views: 3

Q View related articles ¿ 
Carcinus mænas, Pennant.

Mr. Wood Mason exhibited a specimen of Carcinus mcenas, Pennant, taken in 1866 or 1867 at Point de Galle, Ceylon, by Dr. J. Anderson. Comparison of this specimen with those from the Mediterranean lately received from Prof. Cornalia, of Milan, had enabled him to be sure of the correctness of his previous identification from the published figures and descriptions. The species appeared to have an exceedingly wide distribution, being found in abundance on the shores of the British Isles and of the United States, whence it extends to the Arctic Sea, and on all the Mediterranean coasts; it has also been recorded by Heller from Rio Janeiro; and specimens will doubtless ultimately be met with in the Red Sea.-Proceedings of the Asiatic Society of Bengal, November 1873.

\section{Cetacea of the North Sea and the Baltic.}

Professor Malm, in his ' Zoological Observations,' gives a comparative account of fifteen specimens of the common porpoise (Phoccena Linncei) occurring in the Baltic. He describes and figures a gravid female, and young, and mentions the peculiarities of each specimen. He observes that the small tubercles on the front edge of the dorsal fin, on which Dr. Gray has established Phocona tuberculifera, occur very rarely among these animals; he only found it in one specimen (no. 13) out of the whole of the male and female specimens which he examined; and therefore he thinks this species is still doubtful.

Professor Möbius gives an account of a male and female grey grampus (Grampus griseus), which were taken on the 17 th and 19th of February 1871 on the west coast of Holstein, between the Elbe and Eider. I believe this is the first time that this southern species, which sometimes visits the south coast of England, has been recorded as found so far north.

Professor Möbius records the occurrence of the following species in the Little Belt :-

Phocaina communis, F. Cuvier.

Pseudorca crassidens, Gray. November 24, 1861.

Delphinus tursio, Otho Fabricius. June 1870.

Lagenorhynchus albirostris, Gray. Winter 1851-52.

Hyperoodon rostratum, Pontop. December 3, 1807.

J. E. GraY.

On some Extinct Types of Horned Perissodactyles. By EDwaRD D. Cope, of Philadelphia, Penn.

It is well known that the type of Mammalia of the present period, which is preeminently characterized by the presence of osseous horns, is that of the Artiodactyla Ruminantia. At the meeting of the Association of last year, held at Dubuque, I announced that the horned mammals of our Eocene period were most nearly allied to the Proboscidians. I now wish to record the fact (as I believe, for the first time) that the Perissodactyles of the intermediate formation of the Ann. \& Mag. N. Hist. Ser. 4. Vol. xiii. 
Miocene embraced several genera and species of horned giants not very unlike the Eobasileus and Uintatherium in their armature.

While exploring, in connexion with the United States Geological Survey of the Territories, I discovered a, deposit of the remains of numerous individuals of the above character, which included, among other portions, crania in a good state of preservation. Most of these skulls are nearly or quite 3 feet in length, and mostly deprived of their mandibular portions ; these are quite abundant in a separated condition. The crania represent at least six species, while the mandible represents a condition distinct from that of $\mathrm{Ti}$ tanotherium or any allied genus, viz. I. 0, C. 1, P.M. 3, M. 3. The teeth diminish rapidly in size anteriorly; and there is no diastema behind the canines, whose conic erowns do not exceed those of the premolars in length. To the genus and species thus characterized I have elsewhere given the name of Symborodon torvus.

One of the crania, referred to nnder the name of Miobasileus ophryas, is characterized by its strong and convex nasal bones and concave superior outline posteriorly, and by the presence of a massive horn-core on each side of the front, whose outer face is continuous with the inner wall of the orbit, as in the Loxolophodon cornutus. It stood above the eye in life, and diverged from its fellow so as to overhang it. In the specimen which was fully adult they were worn obtuse by use-length about 8 inches, thickness 3 inches. The molar teeth differ from those of Titanotherium Proutii in having cross crests extending inward from the apices of the outer chevrons, each of which dilates into a T-shape near the cones.

The third species is referred to the new genus Symborodon, under the name of $S$. acer. It has overhanging eyebrows and the vertex little concave; but the nasal bones are greatly strengthened, and support on each side near the apex a large curved horn-core 10 inches in length with sharply compressed apex. These horns diverge with an outward and backward curve, and when covered with their sheaths must have considerably exceeded a foot in length. This was a truly formidable monster, considerably exceeding the Indian rhinoceros in size.

The fourth species is allied to the last, and has well developed superciliary crests without horns. The latter are situated well anteriorly, and are short tubercles not more than 3 inches in height. They are directed outward, and have a truncate extremity. The type individual is of rather larger size than those of the other species. There are several crania referable to the three now named. The present one has been named Symborodon helocerus.

Other species, based upon crania without mandibles, were referred to the genus Symborodon.

These animals show true characters of the Perissodactyla in their deeply excavated palate, solid odontoid process, third trochanter of femur (which has also a pit for the round ligament), the divided superior ginglymus of the astragalus, \&c.-Read before the American Association for the Advancement of Science, Portland Meeting, August 20, 1873. 